\title{
Pengajaran Tuhan Yesus Mengenai Toleransi Dan Implementasinya Ditengah Masyarakat Majemuk
}

\author{
Rikardo Dayanto Butar-Butar, ${ }^{1}$ Ester Lina Situmorang, ${ }^{2}$ Jabes Pasaribu ${ }^{3}$ Manahan Uji Simanjuntak \\ Prodi Studi PAK, STT Real Batam \\ Prodi Studi PAK, STT Real Batam \\ Prodi Studi PAK, STT Real Batam \\ Prodi Studi PAK, STT Real Batam \\ rikardobutar@gmail.com
}

\begin{abstract}
The Indonesian Church exists and grows in the midst of a pluralistic society. The society consists of various tribes, religions, races and nationalities. Diversity is often a source of problems in the lives of Indonesian people. Hate speech in the name of religion, ethnicity and creed as well as various acts of intolerance have become an urgent homework to be resolved at this time. Indonesia that stands on diversity faces a formidable challenge to move forward and grow as an independent nation. Tolerance is the attitude and practice of life that is needed in the midst of a plural society. Tolerance is the life and spirit of diversity. Christians as an inseparable part in a plural society must be present to contribute in campaigning and developing the practice of tolerance. Tolerance must be built according to the teachings and example of the life of the Lord Jesus Christ. The teaching of the Lord Jesus Christ about tolerance must be an attitude of thinking, speaking and acting for every believer in the midst of a plural society. The Church of God is obliged to implement the attitude of life, teachings and tolerance practices of the Lord Jesus. Loving all people like yourself, respecting the teachings of other people's religions and beliefs and developing an attitude of forgiveness are teachings that must be implemented to bring about tolerance. Keywords: Tolerance, Compound Society, Jesus Teaching.
\end{abstract}

\begin{abstract}
Abstrak
Gereja Indonesia ada dan tumbuh ditengah-tengah masyarakat majemuk. Masyarakat yang terdiri dari berbagai suku, agama, ras dan bangsa. Keberagaman kerap menjadi sumber persoalan dalam kehidupan masyarakat Indonesia. Ujaran kebencian atas nama agama, suku dan kepercayaan dan juga aksi berbagai intoleransi menjadi perkerjaan rumah yang mendesak untuk diselesaikan saat ini. Indonesia yang berdiri diatas kebhinekaan menghadapi tantangan berat untuk terus maju dan bertumbuh sebagai Negara merdeka. Toleransi adalah sikap dan praktek hidup yang sangat dibutuhkan ditengah masyarakat majemuk. Toleransi merupakan nyawa dan roh keberagaman. Orang Kristen sebagai salah satu bagian tidak terpisahkan dalam masyarakat majemuk wajib hadir memberikan kontribusi dalam mengkampanyekan serta mengembangkan praktek hidup toleransi. Sikap toleransi harus dibangun sesuai ajaran dan teladan hidup Tuhan Yesus Kristus. Pengajaran Tuhan Yesus Kristus tentang toleransi harus menjadi sikap berpikir, berbicara dan bertindak bagi setiap orang percaya ditengah masyarakat majemuk. Gereja Tuhan berkewajiban mengimplementasikan sikap hidup, ajaran dan praktek toleransi Tuhan Yesus. Mengasihi semua orang seperti diri sendiri, menghormati ajaran agama dan keyakinan orang lain serta mengembangkan sikap mengampuni adalah ajaran yang harus diimplementasikan untuk mewujudkan toleransi.

Kata Kunci: Toleransi, Masyarakat Majemuk, Pengajaran Yesus.
\end{abstract}




\section{PENDAHULUAN}

Sebuah realita bahwa Gereja Tuhan atau orang percaya di Indonesia tinggal bersama, berada, bergaul dan berbaur dalam tatanan masyarakat majemuk. Masyarakat yang terdiri dari berbagai ragam suku, agama bahasa dan ras yang tersebar dari Sabang sampai Merauke. Keberagaman tersebut menjadi keunggulan dan keunikan Negara Indonesia sebagai sebuah bangsa yang besar. Selain sebagai sebuah keunggulan dan keunikan, kemajemukan juga menjadi sebuah tantangan berat dalam kehidupan berbangsa dan bernegara. Eksistensi Indonesia sebagai bangsa besar dengan semboyan Bhineka Tunggal Ikanya akhir-akhir ini sedang diuji dengan persoalan besar yang berkaitan dengan masalah keberagaman di Indonesia.

Fransiskus Irwan Widjaja mengutarakan masyarakat Indonesia memiliki berbagai latar belakang yang berbeda satu dengan yang lainnya. Adanya keberagaman atau perbedaan itu mempengaruhi bahasa, budaya, kepercayaan. Secara sosiologis, masyarakat Indonesia adalah masyarakat religius dan mudah menerima kebudayaan yang membawa nilai-nilai spiritual. ${ }^{1}$

Dibalik keunikan nilai-nilai spiritual di atas juga terdapat isu-isu intoleransi menjadi pekerjaan rumah yang sangat mendesak untuk segera ditangani secara serius dalam kehidupan berbangsa dan bernegara saat ini. Intoleransi beragama menduduki posisi teratas dari berbagai praktek intoleransi yang terjadi. Masyarakat Indonesia yang multicultural menganut berbagai agama seperti Islam, Kristen, Katolik, Hindu, Budha, Khonghucu dan aliran kepercayaan menghadapi tantangan yang sama tentang aksi Intoleransi baik antar dan inter beragama.

"Menurut Pusat Penelitian Kependudukan Lembaga Ilmu Pengetahuan Indonesia (LIPI) (2019), terdapat empat faktor yang memperkuat terjadinya intoleransi politik di Indonesia, yaitu religiusitas, media sosial, fanatisme, dan sekularisme. Religiu sitas menjadi faktor yang menarik untuk dikaji lebih dalam. Dalam surveyina Penelitian ini menjelaskan bahwa religiusitas akan menimbulkan fanatisme keagamaan yang tinggi dan menjadi penyebab tingginya ketidakpercayaan dan sinisme terhadap kepercayaan lain. Hal tersebut menjadi pemicu munculnya intoleransi politik dalam masyarakat. Survei yang dilakukan oleh Wahid Foundation dan Lembaga Survei Indonesia (LSI) (dalam DetikNews, 2018), mengungkap bahwa terdapat 59,9\% responden memiliki kelompok kelompok tertentu yang dibenci, khususnya kelompok non-muslim, tionghoa, dan komunis. Bahkan 92,2\% responden tidak setuju apabila kelompok yang dibenci tersebut menduduki pos pemerintahan di Indonesia. ${ }^{2}$

\footnotetext{
${ }^{1}$ Fransiskus Irwan Widjaja, "PLURALITAS DAN TANTANGAN MISI: KERANGKA KONSEPTUAL UNTUK PENDIDIKAN AGAMA KRISTEN DALAM MASYARAKAT MAJEMUK,” Regula Fidei (2019).

${ }^{2}$ Gamal Ferdhi and Subhi Azhari, Mengikis Politik Kebencian (Jakarta: Wahid Foundation, 2018), http://wahidfoundation.org/index.php/publication/detail.40
} 
Dalam Survey yang diadakan LSI (Lembaga Survey Indonesia) yang dirilis pada September 2018, menunjukkan bahwa lebih dari 50\% penduduk Indonesia bersikap intoleran pada agama lain. Survey PPIM yang dirilis pada 16 Oktober 2018 menemukan bahwa mayoritas guru Muslim (63\%) di sekolah-sekolah di Indonesia punya pandangan intoleran terhadap agama dan keyakinan berbeda. ${ }^{3}$

Media social dan ruang-ruang public di Indonesia saat ini diwarnai dengan berbagai aksi ujaran kebencian, hujatan terhadap tokoh dan keyakinan lain yang berpotensi menimbulkan konflik. Perbedaan agama, mazhab, suku, pandangan politik, adalah beberapa alasan melegalkan aksi intoleran. Boleh dikatakan bahwa Indonesia saat ini ada dalam posisi darurat toleransi. Sikap peduli dan empati kepada orang lain sebagai sesama mahluk Tuhan dikesampingkan dan diabaikan karena perbedaan agama dan keyakinan. Membenci dan menyerukan kebencian kepada orang diluar keyakinannya diyakini sebagai sebuah praktek menjalankan ajaran agamanya yang direstui Allah. Merasa dan meyakini hanya agama dan keyakinannya yang paling benar menjadi patokan dalam bersikap terhadap agama dan keyakinan lain. Persoalan ini merupakan masalah yang sangat serius yang dapat merusak tatananan juga harmoni kehidupan berbangsa dan bernegara, karena itu segala sumber daya yang ada wajib dimaksimalkan dan dikerahkan untuk menghentikan semua aksi tersebut.

Dalam prespektif iman Kristen perbedaan, kemajemukan masyarakat Indonesia adalah anugerah Tuhan dan kekayaan besar bangsa yang wajib dijaga dan disyukuri. Kepelbagaian suku, bangsa, ras dan agama adalah keunggulan dan kekuatan Indonesia sebagai bangsa yang besar. Gereja harus bertanggungjawab dan berpartisipasi dalam merawat kemajemukan agama sehingga damai sejahtera Allah di bumi dapat terwujud. Namun realitanya gereja juga ikut berkontribusi dalam praktek intoleransi di Indonesia, baik yang berkaitan antar agama maupun inter beragama. Hal ini tepat seperti penjelasan Fredy Simanjuntak, Pola hubungan merupakan inti dari seluruh pelayanan dan kehadiran Yesus selama melakukan seluruh pekerjaan-Nya di Bumi. Yesus dalam kesehariannya menempatkan diri-Nya di tengah-tengah orang banyak, mulai dari keluarga sampai kepada anak-anak. Apa yang Yesus ajarkan sesuai dengan apa yang Ia lakukan. hubungan penuh kasih dan belas kasihan kepada orang-orang merupakan cermin dari kehidupan Yesus sendiri, penuh kedekatan dan ketidakterpisahan dengan Bapa-Nya. Keunikan itulah yang menempatkan pola hubungan merupakan pusat dari kekristenan itu sendiri yang menjadikan hukum terutama yaitu mengasihi Tuhan Allah setara dengan mengasihi sesama manusia. Allah menjadikan keluarga sebagai tempat untuk manusia dapat belajar saling mengasihi. ${ }^{4}$

\footnotetext{
${ }^{3}$ Luthfi Assyaukanie, “Akar-Akar Legal Intoleransi Dan Diskriminasi Di Indonesia.” (2018).," MAARIF Journal 13, no. 27-42 (2018).

${ }^{4}$ Fredy Simanjuntak, "Problematika Disorganisasi Dan Disharmonisasi Keluarga," in Keluarga Yang Misioner, 2018.
} 
Tugas besar gereja dalam merawat kemajemukan masyarakat semakin berat melihat berbagai fenomena dan tumbuhnya berbagai sikap intoleransi ditengah masarakyat masa kini. Toleransi yang adalah "nyawa" dan "roh" membangun harmoni dalam masyarakat majemuk seolah sirna oleh pancaran pengajaran radikalisme antar dan inter agama yang lambat laun telah merobek semangat kebersamaan dalam kebhinnekaan.

Jamaknya praktek intoleransi yang terjadi di Indonesia dalam dasawarsa terakhir berhasil mengubah sikap dan pandangan masyarakat gotongroyong menjadi bangsa yang egois dan merasa dirinya, ajarannya, kelompoknya, agamanya, sukunya yang paling benar. Sikap ini tidak saja terjadi diluar gereja dan kekristenan, namun dalam gereja dan kekristenan sikap ini tumbuh begitu subur yang berhasil menelurkan berbagai aliran didalam dan diluar gereja. Hal ini menjadi dilema bagi kekristenan masa kini. Sebab didalam dan diluar gereja muncul berbagai pengajaran yang menjauhkan umat Tuhan dari semangat kesatuan sebagai Tubuh Kristus. Tumbuh sikap dan pandangan superioritas atas gereja dan denominasi lain.

"Di satu sisi, gereja dari kalangan Injili kerapkali dicap sebagai kaum pietis, yang hanya memperhatikan sisi rohani manusia dan mengambil sikap acuh tak acuh terhadap kondisi dunia yang sedang terjadi. Di sisi lain, gereja-gereja yang membawa semangat oikumenikal dicap sebagai gereja liberal yang terlalu banyak menekankan sisi kemanusiaan dari pelayanan gereja dan membuat kebenaran Alkitab menjadi relative."5

Tuhan Yesus Kristus sebagai patokan, tokoh central dalam iman Kristen dalam praktek hidup pelayanan dan pengajaranNya mewariskan nilai luhur tentang toleransi. Manusia sebagai "sesama" wajib hidup harmoni dalam kasih. Namun praktek hidup dan pengajaran Kristus tersebut tidak teraplikasi dengan maksimal dalam praktek kehidupan iman Kristen masa kini. Sikap dan pandangan orang Kristen masa kini jauh dari telada, praktek dan pengajaran Kristus tentang toleransi. Akibatnya konflik dan perpecahan di dalam dan di luar gereja dengan berbagai alasannya menjadi perbincangan dan diskusi tanpa kesimpulan hingga saat ini.

Menyadari maraknya praktek dan aksi intoleransi antar umat beragama serta suburnnya tumbuh konflik didalam dan diluar gereja hingga saat ini, maka diperlukan berbagai kontribusi untuk mewujudkan harmoni dalam kehidupan berbangsa dan bernegara. Gereja Tuhan harus hadir merawat dan menumbuhkan semangat toleransi sebagaimana diajar dan diwariskan Tuhan Yesus Kristus sebagai patokan berpikir, bersikap, serta bertindak setiap orang percaya. Pengajaran, gagasan dan perintah Tuhan Yesus tentang toleransi harus dibumikan sehingga praktek intoleransi dapat direduksi. Nilai-nilai Toleransi yang diajarkan Tuhan Yesus Kristus dalam praktek hidup dan pelayanNya wajib dipahami dan diamalkan setiap orang percaya.

\footnotetext{
${ }^{5}$ Yakub Susabda, Kaum Injili (Malang: Gandum Mas, 1991). Hal, 25
} 
Gereja harus bebas dari pola pikir dan aksi intoleransi, karena itu pengajaran Tuhan Yesus tentang toleransi harus disuarakan kuat-kuat ditengah-tengah umat. Dengan demikian interaksi social orang percaya dengan semua golongan ditengah masyarakat majemuk berjalan dengan baik sehingga kabar baik dan kasih Kristus tersampaikan dan menjangkau semua kalangan.

\section{METODE}

Tulisan ini ditulis dengan menggunakan metode penelitian kualitatif deskriptif, untuk menganalis tentang pengajaran Tuhan Yesus mengenai toleransi Beragama. Artikel ini mengumpulkan fakta dan data tentang toleransi beragama dalam pengajaran Tuhan Yesus. Metode deskriptif digunakan untuk menjelaskan pengajaran Tuhan Yesus tentang toleransi sebagai sebuah variable yang berkaitan implementasinya dalam kehidupan masyarakat majemuk saat ini.

\section{HASIL DAN PEMBAHASAN}

\section{Pengajaran Tuhan Yesus Tentang Toleransi Beragama.}

Toleransi merupakan modal utama untuk dapat hidup berdampingan ditengah masyarakat majemuk. Gereja Tuhan sebagai bagian dari masyarakat plural wajib mempraktekkan dan menghidupi pengajaran dan teladan Tuhan Yesus Kristus. Toleransi yang adalah nyawa kerukunan hidup harus mendapatkan porsi maksimal dan pengajaran dan praktek kehidupan dalam interaksi social. "Toleransi yang dipahami sebagai tolerantia, berarti memberi kelonggaran, kelembutan hati, keringanan dan kesabaran." Sebab itu dapat dipahami istilah toleransi mengacu pada sikap terbuka, lapang dada, suka rela dan kelembutan terhadap orang lain yang memilliki perbedaan pandangan dan keyakinan. Unesco mengartikan toleransi sebagai sikap saling menghormati, saling menerima, saling menghargai di tengah keragaman budaya, kebebasan berekspresi dan karakter manusia."7

Sebab itu kata toleransi dapat dipahami sebagai sikap, pengakuan dan penerimaan bahwa setiap orang adalah setara, sederajat serta memilki harkat dan martabat yang sama. Dengan demikian setiap orang wajib menerima orang lain dengan sikap positif, menghargai orang lain dalam rangka menggunakan hak asasinya sebagai manusia. Toleransi beragama merupakan sikap dan pandangan yang mencakup masalah-masalah keyakinan dalam diri manusia yang berhubungan dengan ajaran, nilai dan norma atau ketuhanan yang diyakininya. Setiap orang harus dihormati dan diberikan kebebasan untuk meyakini dan memeluk agama serta melaksanaan ajaran-ajaran yang dianut atau diyakininya. ${ }^{8}$ Diketahui bersama bahwa; "Sumber utama bagi pandangan dan sikap Kristen dalam Alkitab Perjanjian Baru tentang pluralisme dan toleransi adalah teladan yang diperlihatkan Yesus. Yesus atau agama Kristen muncul, berkarya dan beredar mulai-mula

\footnotetext{
${ }^{6}$ Casram Casram, "Membangun Sikap Toleransi Beragama Dalam Masyarakat Plural," Wawasan: Jurnal Ilmiah Agama dan Sosial Budaya (2016). Hal, 188

${ }^{7}$ Ibid.

${ }^{8}$ Ibid.
} 
di dalam kalangan masyarakat dan agama Yahudi. Jadi ketika hal itu muncul, pluralitas sudah menjadi bagiannya. ${ }^{9}$

Tuhan Yesus dalam teladan hidup dan pengajaranya mewariskan nilai toleransi yang terdokumentasi dengan baik dalam kitab suci Alkitab merupakan tuntunan wajib bagi orang percaya untuk berpikir dan bertindak. Ajaran Tuhan Yesus tentang toleransi begitu tegas, lugas dan jelas sehingga mudah diterima. Karena itu tanpa ragu gereja Tuhan seharusnya bebas dari aksi intoleransi apabila standar berpikir dan bertindak sesuai Alkitab. Pengajaran Tuhan Yesus Kristus tentang toleransi dapat dipahami dari berbagai pengajaran berikut;

\section{Pertama; Perintah Untuk Mengasihi sesama seperti diri sendiri.}

Perjanjian Baru mencatat salah satu inti utama pengajaran Tuhan Yesus yang berkaitan dengan toleransi adalah mengasihi sesama manusia seperti diri sendiri. Tuhan Yesus dalam pengajaranNya menempatkan manusia sebagai sesama yang harus dipandang dan diperlakukan sebagai objek kasih dimana ukuran perlakuan kepada orang lain tidak mengenal batas agama, suku dan ras tetapi harus didasarkan pada kasih. Perintah Tuhan Yesus untuk mengasihi sesama manusia seperti diri sendiri dalam Matius 22:39, bukti nyata pengajaran Tuhan Yesus tentang posisi orang lain bagi gereja Tuhan. Dalam pengajaran TUhan Yesus semua orang adalah sesama yang harus dikasihi dengan standard seperti mengasihi diri sendiri. Orang lain dari agama dan keyakinan manapun adalah sesama yang harus dikasihi dan dihormati. Setiap orang bernilai dihadapan Tuhan sebab itu iman Kristen harus menumbuhkan sikap saling mempedulikan, memberi, menolong, memperhatikan, bahkan berkorban. "Dengan kata lain kasih melarutkan segala perbedaan, kasih yang mempersatukan orang-orang yang berpotensi hidup saling membenci, menyakiti bahkan saling membunuh."

Pengajaran Tuhan Yesus untuk mengasihi sesama berulangkali dicatat dalam injil. Perintah untuk mengashi sesame merupakan salah satu pusat dan konsentrasi pengajaran Tuhan Yesus dalam pelayananNya di bumi. Injil Yohanes mencatat bahwa Yesus memerintahkan para murid untuk saling mengasihi. Yohanes 13:35-35, memerintahkan para murid supaya saling mengasihi seperti Kristus mengasihi mereka. Diperintahkan bahwa setiap murid harus saling mengasihi, dan sebagai identitas murid Kristus.

Dalam pengajaran berikutnya Yesus mengatakan dalam Yohanes 15:12, dikatakan, Inilah perintahKu supaya kamu saling mengasihi, seperti $\mathrm{AKu}$ telah mengasihi kamu, Dilanjutkan kembali dalam Yohanes 15:17, dengan tegas Yesus memberikan perintah; Inilah perintahKu kepadamu: Kasihilah seorang akan yang lain. Dari berbagai perintah Tuhan Yesus tentang mengasihi sesama memiliki makna dan pengertian yang maksimal

\footnotetext{
${ }^{9}$ Stanley R. Rambitan, "Pluralitas Agama Dalam Pandangan Kristen," Shanan Journal Pendidikan Agama Kristen 1 (2017). Hal, 99

${ }^{10}$ Christoper J.H. Wright, Becoming Like Jesus (Jawa Timur: Literatur Perkantas Jawa Timur, 2017). Hal, 
tentang sikap orang percaya terhadap agama lain. Semua orang adalah sesama bagi orang percaya, karena itu sikap intoleransi sangat diharamkan dan toleransi wajib di junjung tinggi dalam paraktek berpikir dan bertindak terhadap orang lain.

Perintah mengasihi setiap orang sebagai sesama yang tidak boleh diabaikan, dibiarkan atau dihina ditegaskan kembali dalam pengajaran Tuhan Yesus dalam kisah orang Samaria yang murah hati (Lukas 10:25-37). Kisah orang Samaria yang murah hati merupakan salah satu pengajaran terbaik Tuhan Yesus tentang sesame manusia. Pengajaran yang menghancurkan paradigma para ahli taurat yang merasa hidup berkenan kepada Allah karena dalam kehidupan senantiasa memakai jubah agama. Kisah orang samaria yang murah hati menegaskan bahwa setiap orang adalah sesame yang patut ditolong, diperhatikan. Identitas sebagai manusia terletak dari cara memperlakukan orang lain seperti diri sendiri bukan baju atau jubah agama.

Perintah Tuhan Yesus untuk mengasihi sesama manusia seperti diri sendiri adalah pengajaran dan sikap tertinggi tentang toleransi. Setiap orang adalah sesame yang wajib dikasihi, dihormati, ditolong, diperhatikan tanpa dibebani oleh pertimbangan agama dan keyakinan orang lain. Standard mengasihi dan memperlakukan orang lain yang ditetapkan dan diajarkan Tuhan Yesus adalah seperti mengasihi diri sendiri. Standard ini sangat mudah, sederha, mudah dicerna dan diterima. Setiap orang harus diperlakukan sebagaimana memperlakukan diri sendiri. Dan pengajaran Tuhan Yesus tentang mengasihi sesama seperti diri sendiri dalam prakteknya sangat memungkinkan untuk dilakukan. Standardnya sangat sederhana. Yesus berkata; "Segala sesuatu yang kamu kehendaki supaya orang perbuat kepadamu, perbuatlah demikian juga kepada mereka. Itulah isi seluruh hukum Taurat dan kitab para nabi. (Matius 7:12). Menerima, mengasihi setiap orang sebagai sesama merupakan pokok pengajaran Tuhan Yesus yang wajib dihidupi oleh setiap orang percaya. Praktek intoleransi sama sekali tidak dibenarkan dalam pengajaran Tuhan Yesus Kristus. Toleransi wajib hadir dalam praktek pemikiran dan tindakan orang percaya dengan mengasihi orang lain seperti diri sendiri. Dan menerima bahwa setiap orang adalah sesama, apapun agama dan kepercayaannya.

\section{Kedua; Teladan Penerimaan Yesus kepada Perempuan Samaria.}

Yesus adalah guru agung yang sangat efektif dalam menyampaikan ide, gagasan dan pemikiranNya. Hidup ditengah masyarakat intoleran yang menolak atau tidak bergaul dengan orang lain karena perbedaan adat istiadat dan keyakinan diruntuhkan Tuhan Yesus melalui teladan dalam pengajaran yang sangat efektif. Penerimaan Yesus terhadap perempuan Samaria adalah bentuk pengajaran yang disampaikan melalui metode praktek langsung dari Tuhan Yesus yang adalah orang Yahudi untuk meruntuhkan tembok tebal aksi intoleransi orang Yahudi terhadap orang Samaria, dimana orang Yahudi tidak mau bergaul dengan orang Samaria. (Yohanes 4:9) 
Dari teladan penerimaan Yesus terhadap perempuan Samaria disampaikan pesan dan ajaran bahwa Yesus tidak pernah setuju dengan perbuatan Intoleransi. Bagi Tuhan Yesus semua orang memiliki kedudukan dan derajat yang sama dalam. Penerimaan terhadap perempuan Samaria adalah pesan dan ajaran bahwa tidak ada suku bangsa, ras, kelompok atau agama yang lebih rendah dari yang lainnya. "Yesus menerima keberadaan bangsa-bangsa lain dan mau bergaul dengan mereka, dan bukan itu saja Yesus tidak segansegan belajar dan mengambil contoh yang baik dari bangsa asing itu bagi ajaran moral-etisNya seperti perempuan Samaria tersebut.",11

Pandangan dan sikap Yesus terhadap bangsa, agama, suku lain dalam kisah percakapan dengan perempuan Samaria menunjukkan pengakuan dan penerimaan Yesus terhadap eksistensi mereka; "dan bahwa mereka adalah bangsa yang perlu diperlakukan secara baik, yaitu dengan memberikan perhatian dan mengangkat harkat martabat hidup mereka. Juga bahwa, masyarakat lain ini menjadi tempat menyampaikan kabar baik, Injil atau berita keselamatan, supaya mereka dapat selamat; atau supaya mereka dapat dibebaskan dari belenggu kebodohan, kemiskinan, kesakitan dan penderitaan, dan mereka dapat hidup damai sejahtera." 12

Dari ajaran Tuhan Yesus Kristus dalam Perjanjian Baru tampak jelas bahwa keberagaman, perbedaan atau kemajemukan bukan untuk dipertentangkan atau juga pemisah kasih sebagai sesama. Perbedaan adalah karunia Allah yang memberikan warna indah dalam kehidupan. Sebab itu sikap dan pandangan eksklusif sempit harus diruntuhkan, karena menjadi penghambat memenuhi amanat Agung Kristus, menjadi saksiNya. Praktek hidup ketika berhadapan dengan keberagaman dalam masyarakat harus mencerminkan wajah Kristus yang akomodatif terhadap semua orang, semua agama dan keyakinan adalah identitas yang wajib melekat dalam diri setiap orang percaya. Tuhan Yesus Kristus mengajarkan Kashilah sesamamu seperti dirimu sendiri, menjadi dasar berpikir dan berperilaku orang percaya, sebab ajaran tersebut sudah nyata dalam praktek pelayanan Kristus, penerimaan kepada perempuan Samaria menjadi salah satu contohnya.

\section{Kedua; Sikap Dan Pandangan Kristus tentang Hukum Taurat}

Dengan tegas Tuhan Yesus menyatakan sikap dan pandanganNya terhadap hukum Taurat sebagai dasar keyakinan iman orang Yahudi. Menyikapi keyakinan mereka dengan tegas Yesus berkata bahwa tujuan kedatanganNya bukan untuk meniadakan hukum Taurat atau kitab para nabi. Tetapi tujuan kedatanganNya melainkan untuk menggenapinya (Matius 5:17). Pernyataan Tuhan Yesus tentang hokum taurat tentu saja sangat sensitive bagi orang Yahudi, "mengingat bahwa Hukum Taurat merupakan dasar, landasan hidup keagamaan dan keyakinan bagi orang Israel sesuai Perjanjian Lama."13

\footnotetext{
${ }^{11}$ Yushak Soesilo, “Gereja Dan Pluralisme Agama Dalam Konteks Di Indonesia,” Jurnal Antusias (2011).

12 Stanley R. Rambitan, "Pluralitas Agama Dalam Pandangan Kristen.” Hal, 101

${ }^{13}$ Donald Guthrie, Teologi Perjanjian Baru II (Jakarta: BPK Gunung Mulia, 1995)., Hal 341
} 
Perjanjian Baru mencatat bahwa Tuhan Yesus berkali-kali menentang dan mengecam para imam-imam dan ahli-ahli Taurat sebagai petinggi dan pengajar agama Yahudi, namun terhadap dasar keyakinan agama Israel yaitu Taurat Tuhan Yesus sangat menghargai dan menghormatinya. Dengan tegas Tuhan Yesus menjelaskan tentang posisi hokum Taurat dalam pandanganNya. Kedatangan Yesus bukan untuk meniadakan Hukum Taurat, tetapi menggenapinya. Bahkan satu iota atau satu titikpun tidak akan ditiadakan dari Hukum Taurat, sebelum semuanya terjadi (Matius 5:17-18). Bahkan lebih lanjut Karena itu siapa yang meniadakan salah satu perintah hukum Taurat sekalipun yang paling kecil, dan mengajarkannya demikian kepada orang lain, ia akan menduduki tempat yang paling rendah di dalam Kerajaan Sorga; tetapi siapa yang melakukan dan mengajarkan segala perintah-perintah hukum Taurat, ia akan menduduki tempat yang tinggi di dalam Kerajaan Sorga (Matius 5:19).

Hukum Taurat yang ditetapkan Musa atas Israel berlaku sepanjang hidup dan pelayanan Tuhan Yesus. Namun "Dalam pengajaran-pengajaranNya Yesus Kristus menguatkan Hukum-hukum Musa dengan menyatakan bahwa hukum-hukum itu harus digenapi (Matius 5:17-19). Bagi Yesus Kristus Hukum Taurat adalah pernyataan kekal kehendak Allah yang tidak dapat diubah." ${ }^{14}$ Pernyataan Yesus tersebut membantah anggapan dan pemikiran orang-orang Yahudi sebelumnya; Mereka semua takjub, sehingga mereka memperbincangkannya, katanya: "Apa ini? Suatu ajaran baru. Ia berkata-kata dengan kuasa. Roh-roh jahatpun diperintah-Nya dan mereka taat kepada-Nya." (Markus 1:27).

Yesus sangat menghormati dan menjunjung tinggi hukum Taurat sebagai dasar keagaamaan bangsa Israel, Ia hidup sesuai dengan Hukum Taurat, tidak ada sedikitpun penolakan Yesus atas hukum Musa. "Yesus adalah orang Yahudi yang tidak menolak ajaran dan prinsip hidup orang Yahudi." ${ }^{15}$ Yang ditentang oleh Tuhan Yesus adalah para pengajar taurat yang mengajar, menafsirkan Hukum Musa diluar kebenaran. "Karena mereka atau para pengajar Israel mengajarkan Hukum Musa tetapi gagal menjadi teladan dari apa yang mereka ajarkan." ${ }^{16}$ Realitas tersebutlah yang menjadi alasan Yesus berkata; "Sebab itu turutilah dan lakukanlah segala sesuatu yang mereka ajarkan kepadamu, tetapi janganlah kamu turuti perbuatan-perbuatan mereka, karena mereka mengajarkannya tetapi tidak melakukannya. (Matius 23:3).

Penghargaan, penerimaan dan sikap Yesus terhadap Hukum Taurat sebagai dasar agama bangsa Israel terdokumentasi dengan baik dalam Kisah Perjanjian Baru. Pandangan dan sikap ini menjadi dasar keyakinan bahwa Tuhan Yesus Kristus tidak pernah menunjukkan sikap intoleran terhadap kebenaran dalam Hukum Taurat. Tuhan Yesus

${ }^{14}$ Chris Marantika, Kristologi (Yogyakarta: Iman Press, 2008). Hal, 74

${ }^{15}$ Sarah Andrianti, "Yesus, Taurat Dan Budaya," Jurnal Antusias (2013). Hal, 2

${ }^{16}$ Noel Ghota and Prima Bayu, "BELAJAR MENGHARGAI KEARIFAN LOKAL DARI YESUS DALAM MATIUS 22:32.," Jurnal Teologi Kristen VISIO DEI 1, no. 2 (2019). Hal, 174 
sangat menjunjung tinggi nilai dan pengajaran dalam hukum Taurat, Dia hanya mengecam praktek hidup para pengajar Hukum Musa yang tidak sesuai dengan ajaran Hukum Taurat. Kemunafikan hidup dan penafsiran yang keliru dari Hukum Musa menjadi alasan lain sehingga Yesus mengecam mereka.

\section{Ketiga: Keputusan Yesus Tidak Menghukum Perempuan Yang tertangkap basah berbuat zinah.}

Catatan dalam Yohanes pasal 8 tentang ahli-ahli Taurat dan orang-orang Farisi yang membawa seorang perempuan yang kedapatan berbuat zinah (Yohanes 8:3) memberikan informasi dan konfirmasi yang kuat tentang pandangan dan sikap Tuhan Yesus yang sangat menjunjung tinggi toleransi. Tindakan dan keputusan Tuhan Yesus atas tuntutan para imam-imam dan orang-orang Farisi supaya melempari perempuan itu dengan batu sesuai hokum Musa benar-benar diluar dugaan orang banyak. Dengan tegas Yesus berkata "Barangsiapa di antara kamu tidak berdosa, hendaklah ia yang pertama melemparkan batu kepada perempuan itu." Dari peristiwa ini Tuhan Yesus memberikan pelajaran bagi semua orang tentang arti dan makna dari toleransi yang sesungguhnya.

Penerimaan, maaf, pengampunan, kasih adalah nyawa dari Toleransi. Sikap itulah yang dipraktekkan Kristus menjadi pelajaran berharga tentang makna toleransi. Dosa perzinahan perempuan tersebut sama sekali tidak dapat ditoleransi, namun Tuhan Yesus memberikan pelajaran tentang makna toleransi. Hukum harus ditegakkan namun kasih dan penerimaan memampukan manusia memahami bahwa semua orang memiliki sisi gelapnya masing-masing. Karena itulah Yesus berkata "barangsiapa tidak berdosa hendaklah menjadi yang pertama melempar perempuan itu dengan batu." (Yohanes 8:7). Ajaran Tuhan Yesus tentang toleransi, atau sikap menerima sesame dalam kasih Kristus menyadarkan semua ahli-ahli taurat dan orang-orang Farisi bahwa mereka juga adalah orang berdosa yang tidak lupat dalam dosa dan kelalaian.

Sikap Toleransi Tuhan Yesus dalam kasus perempuan tersebut memberikan pelajaran luar penting bahwa toleransi terwujud ketika ada kasih, maaf, pengampunan dan penerimaan. Tanpa semuanya itu akan terbentuk sikap dan praktek hidup merasa diri lebih baik, lebih benar, lebih unggul dan lain sebagainya yang menyeret kepada praktek intoleransi. Teladan Kristus tentang makna dan artii toleransi tergambar jelas dari perkataan, tindakan dan perlakuaanNya kepada perempuan tersebut. Yesus bukan saja tidak menghukumnya, tetapi menerimanya dengan penuh kasih. Bahkan lebih dari itu, "Bagian ini diakhiri dengan Yesus yang membiarkan perempuan itu pergi dengan selamat. Yesus tidak membiarkannya binasa tetapi menyelamatkannya dari kegelapan."17

\footnotetext{
${ }^{17}$ Maksimilianus Jemali, "UPAYA PASTORAL UNTUK MENINGKATKAN PERAN KAUM PEREMPUAN DALAM KEHIDUPAN MENGGEREJA," Jurnal Pendidikan dan Kebudayaan Missio, no. 10 (2018): 204-218. Hal, 209
} 


\section{Implementasi Toleransi Dalam Masyarakat Majemuk}

Indonesia sebagai sebuah bangsa yang terdiri dari berbagai suku bangsa, agama, suku, bahasa dan ras menghadapi berbagai persoalan yang berkaitan dengan keberagaman. 'Dalam masyarakat majemuk, seperti Indonesia, masalah-masalah yang kritikal yang biasanya dihadapi adalah hubungan antara sistem nasional atau pemerintahan negara, dengan masyarakat-masyarakat suku bangsa yang menjadi rakyat negara tersebut; hubungan di antara sukubangsa-sukubangsa yang berbeda kebudayaannya (termasuk keyakinan keyakinan keagamaannya); dan hubungan di antara sesama warga masyarakat di tempat tempat umum, terutama di pasar dan berbagai pusat kegiatan pelayanan ekonomi."18 Menyikapi berbagai persoalan yang terjadi, sebagai gereja Tuhan yang wajib hidup berpikir dan bertindak sesuai dengan praktek hidup Tuhan Yesus Kristus hadir merajut kebersamaan dalam perbedaan dengan mengimplementasikan praktek hidup dan pengajaran Tuhan Yesus Kristus tentang toleransi.

Berdasarkan pengajaran Tuhan Yesus tentang toleransi orang percaya harus mengimplementasikan sikap dan praktek hidup;

\section{Pertama; Mengasihi semua orang seperti diri sendiri.}

Sikap dan praktek toleransi terhadap semua orang yang harus dikembangkan oleh orang percaya ditengah masyarakat majemuk sesuai pengajaran Tuhan Yesus Kristus adalah mengasihi semua orang seperti diri sendiri. "Kasih adalah undang-undang Dasar Kerajaan Allah. Kasih tidak dapat berbuat jahat kepada sesama manusia merupakan petujuk dan tuntunan hidup sehingga orang Kristen terhindar dari perbuatan jahat dan aksi intoleransi." 19

Mengasihi semua orang seperti diri sendiri merupakan ajaran, perintah dan hidup Tuhan Yesus sendiri harus menjadi praktek hidup yang wajib di implementasikan dalam kehidupan social ditengah masyarakat majemuk. Dengan mengasihi semua orang seperti diri sendiri maka perbedaan bukanlah pemisah namun kekuatan yang memberi warna. Dengan mengasihi sesama seperti diri sendiri orang percaya memiliki kemampuan menerima keunggulan dan kelemahan setiap orang tanpa membedakan latar belakang suku, agama, bahasa dan kepercayaan. Mengasihi orang lain seperti diri sendiri akan meminimalisir bahkan menghilangkan konflik dan konfrontasi karena perbedaan. Tuhan Yesus sudah mengajarkan, memerintahkan, dan menghidupinya maka setiap orang percaya wajib melakukan dan mempraktekkan dalam pikiran dan perbuatan.

\section{Kedua; Menghormati Ajaran Dan Keyakinan Orang Lain.}

Sumber utama masalah kemajemukan adalah sikap menganggap agama dan keyakinan sendiri yang paling baik, paling benar, paling sempurna. Memandang rendah

\footnotetext{
${ }^{18}$ Parsudi Suparlan, "Masyarakat Majemuk Dan Perawatannya," Antropologi Indonesia (2014). Hal, 3

${ }^{19}$ Andrianti, "Yesus, Taurat Dan Budaya." Hal, 4
} 
ajaran, agama dan keyakinan orang lain. "Dalam masyarakat multikultural, pengikut atau pemeluk agama memainkan peranan dominan bagi ajaran agama yang dipeluknya atau bahkan di antara mereka ada sekelompok orang yang acuh terhadap agama yang mereka peluk. Kenyaataan seperti ini akan mengganggu dan juga sekaligus membantu memahami keberadaan suatu agama dengan umatnya. ${ }^{20}$

Toleransi inter dan antar agama, suku, ras dan keyakinan akan terwujud ketika sikap menghormati ajaran agama dan keyakinan orang lain diwujudkan dalam sikap dan perbuatan. Praktek penghormatan Tuhan Yesus terhadap Hukum Taurat menjadi dasar dan landasan yang wajib diteladani dalam praktek kehidupan social orang percaya. "Menghormati ajaran dan keyakinan orang lain diwujudkan dalam toleransi bisa menekan atau meminimalisasi bentrokan di antara mereka. Toleransi beragama yang dikembangkan bukan hanya menghargai teologi dan iman masing-masing agama dan umat beragama, tetapi juga memahami dan menghargai budaya dari umat beragama tersebut." ${ }^{21}$ Sikap Menghormati Agama dan Keyakinan orang lain harus diwujudkan dalam pikiran, perkatan dan perbuatan sebagaimana telah dilakukan oleh Tuhan Yesus Kristus.

\section{Ketiga: Mengembangkan Sikap dan Praktek Hidup Mengampuni.}

Merasa diri paling benar adalah akar praktek intoleransi dalam masyarakat majemuk. Mengembangkan sikap mengampuni menjadi modal dasar mampu bersikap toleran terhadap sesama. Sikap ini wajib dikembangkan oleh setiap orang percaya sebab merupakan ajaran dan praktek langsung hidup Tuhan Yesus Kristus. Perlakuan Kristus terhadap perempuan yang kedapatan berbuat zinah dalam Yohanes pasal delapan menjadi dasar dan landasan bertindak toleran dengan mengembangkan praktek hidup mengampuni, karena sesungguhnya tidak ada orang yang tidak berdosa. Tidak ada orang yang lebih baik dari yang lain. Praktek hidup munafik dan merasa lebih layak dari yang lain adalah benih intoleransi yang wajib diabaikan.

Yesus Kristus telah mengajar dan mempraktekkan hidup mengampuni, merangkul orang yang berdosa, mengajaknya meninggalkan kegelapan menuju terang hidup. Demikian juga setiap orang percaya mempersiapkan diri bertindak seperti Yesus dengan tidak mencari-cari kesalahan orang lain, atau merasa diri lebih benar dari yang lain.

\section{KESIMPULAN}

Gereja berada ditengah masyarakat majemuk. Kabar baik tentang kasih Kristus harus disampaikan kepada seluruh lapisan masyarakat tanapa memandang suku, bangsa ras dan agama. Persoalan yang timbul adalah adanya penolakan, gejolak dan praktek intoleransi baik atar suku agama dan ras yang terjadi. Berbagai praktek intoleransi yang terjadi menjadi penghambat pertumbuhan pembangunan bangsa dan kemajuan bangsa.

\footnotetext{
${ }^{20}$ Casram, "Membangun Sikap Toleransi Beragama Dalam Masyarakat Plural.” Hal, 190

${ }^{21}$ Rosalina Ginting and Kiki Ayaningrum, "Toleransi Dalam Masyarakat Plural," Jurnal Majalah Ilmiah Lontar (2009). Hal, 191
} 
Karena itu sikap da praktek intoleransi harus disingkirkan dari bumi Indonesia yang dibangun diatas keberagaman dan kebhinekaan.

Pengajaran, perintah dan paktek hidup Tuhan Yesus Kristus tentang Toleransi menjadi dasar dan landasan bagi setiap orang percaya berpikir, berbicara dan berperilaku terhadap orang lain. Dalam praktek hidup dan pengajaranNya Tuhan Kristus mewariskan ajaran dan sikap toleransi terhadap sesama berdasarkan kebenaran firman Allah, yang wajib diimplementasikan setiap orang percaya dalam praktek kehidupan social setiap hari yakni; Pertama; Orang Percaya harus mengasihi semua orang seperti diri sendiri. Hal ini merupakan ajaran dan perintah Tuhan Yesus Kristus sehingga mampu bersikap Toleran terhadap sesama karena mengasihi setiap orang dari agama, suku, bangsa manapun seperti diri sendiri. Kedua; Menghargai dan menghormati keyakinan ajaran agama orang lain. Sikap toleransi akan terwujud ketika ada pengakuan dan penghormatan terhadap agama dan keyakinan orang lain. Menghormati ajaran agama lain adalah sikap postif dalam menumbuhkan toleransi sebagaimana nyata dalam praktek kehidupan Tuhan Yesus ditengah-tengah bangsa Yahudi. Ketiga; Mengembangkan praktek hidup mengampuni setiap orang, tidak menganggap diri sendiri lebih superior disbanding yang lain. Sikap yang demikian akan menumbuhkan semangant toleransi kepada orang lain, karena akan menjauhkan diri dari kemunafikan, merasa diri benar, lebih baik dari yang lain. Perlakuan Tuhan Yesus kepada perempuan yang kedapatan berzinah sebagai bukti nyata bahwa sikap dan tindakan mengampuni wajib dipraktekkan kepada semua orang.

Toleransi tidak tumbuh sendiri, perlu diajarkan, dikembangkan dan di implementasikan. Gereja sebagai tubuh Kristus harus menjadi pionir memerangi praktek intoleransi dengan menumbuhkan toleransi sesuai pengajaran dan praktek hidup Tuhan Yesus Kristus. Dengan demikian masyarakat Indonesia yang multicultural dapat hidup berdampingan dalam harmoni keberagaman.

\section{KEPUSTAKAAN}

Andrianti, Sarah. "Yesus, Taurat Dan Budaya.” Jurnal Antusias (2013).

Assyaukanie, Luthfi. "Akar-Akar Legal Intoleransi Dan Diskriminasi Di Indonesia." (2018).” MAARIF Journal 13, no. 27-42 (2018).

Casram, Casram. "Membangun Sikap Toleransi Beragama Dalam Masyarakat Plural." Wawasan: Jurnal Ilmiah Agama dan Sosial Budaya (2016).

Ferdhi, Gamal, and Subhi Azhari. Mengikis Politik Kebencian. Jakarta: Wahid Foundation, 2018. http://wahidfoundation.org/index.php/publication/detail.

Ghota, Noel, and Prima Bayu. "BELAJAR MENGHARGAI KEARIFAN LOKAL DARI YESUS DALAM MATIUS 22:32.” Jurnal Teologi Kristen VISIO DEI 1, no. 2 (2019).

Ginting, Rosalina, and Kiki Ayaningrum. “Toleransi Dalam Masyarakat Plural.” Jurnal Majalah Ilmiah Lontar (2009).

Guthrie, Donald. Teologi Perjanjian Baru II. Jakarta: BPK Gunung Mulia, 1995.

Jemali, Maksimilianus. "UPAYA PASTORAL UNTUK MENINGKATKAN PERAN KAUM PEREMPUAN DALAM KEHIDUPAN MENGGEREJA.” Jurnal Pendidikan 
dan Kebudayaan Missio, no. 10 (2018): 204-218.

Marantika, Chris. Kristologi. Yogyakarta: Iman Press, 2008.

Simanjuntak, Fredy. "Problematika Disorganisasi Dan Disharmonisasi Keluarga." In Keluarga Yang Misioner, 2018.

Soesilo, Yushak. “Gereja Dan Pluralisme Agama Dalam Konteks Di Indonesia.” Jurnal Antusias (2011).

Stanley R. Rambitan. "Pluralitas Agama Dalam Pandangan Kristen.” Shanan Journal Pendidikan Agama Kristen 1 (2017).

Suparlan, Parsudi. "Masyarakat Majemuk Dan Perawatannya." Antropologi Indonesia (2014).

Susabda, Yakub. Kaum Injili. Malang: Gandum Mas, 1991.

Widjaja, Fransiskus Irwan. "PLURALITAS DAN TANTANGAN MISI: KERANGKA KONSEPTUAL UNTUK PENDIDIKAN AGAMA KRISTEN DALAM MASYARAKAT MAJEMUK." Regula Fidei (2019).

Wright, Christoper J.H. Becoming Like Jesus. Jawa Timur: Literatur Perkantas Jawa Timur, 2017. 